\title{
ABSTRACT
}

Nomadic Performativity and the Immanent Ethics of Life

This essay discusses Gilles Deleuze and Félix Guattari's notion of nomadology, which can be used as the basis for an ontological and aesthetic alternative to our understanding of representational theatre. Referring to different meanings of nomadology, the essay argues for the notion of nomadic performativity, which

can be applied to recent non-representational performative practices. For this purpose the essay makes an indirect comparison between Deleuze and Guattari's philosophical ideas and their sporadic insights into art, such as Francis Bacon's paintings and Antonin Artaud's theatre. Deleuze discusses theatre in "One Less

Manifesto", his only text directly dedicated to theatre and to Carmelo Bene's productions. Referring to the structural deformations in Bene's work, Deleuze argues for non-representational theatre, based not on representation and identity

but on continuous variation and differentiation. In other words, if theatre as a form of representation creates a striated and hierarchized space that embodies and increases power, the non-representational theatre creates a nomadic smooth space of continuous variation, which transposes everything into a constant becoming. In this respect nomadic performativity covers these meanings: first, it is a distribution of intensities, which come to replace forms, bonds, organized hierarchies; second, it refers to fusional multiplicities rather than self-identical subjects; and third, it opens up the potential for change and "becoming-minor" instead of representing major figures of power.

Keywords: nomadism, nomadic performativity, the body without organs, Deleuze and Guattari, Artaud, Bene, Castellucci.

BIOGRAPHY

Audronė Žukauskaite is senior researcher at the Lithuanian Culture Research Institute. Her recent publications include "Ethics between Particularity and Universality" (Deleuze and Ethics, Edinburgh University Press, 2011); "Potentiality as

a Life: Deleuze, Agamben, Beckett" (Deleuze Studies, vol. 6.4, 2012); "Intensive

Multiplicities in A Thousand Plateaus" (Understanding Deleuze, Understanding Modernism, Bloomsbury, 2014); the monograph Gilles Deleuze and Felix Guattari's

Philosophy: The Logic of Multiplicity (Baltos lankos, Vilnius 2011), and an edited volume Intensities and Flows: Gilles Deleuze's Philosophy in the Context of Contemporary Art and Politics (LKTI, Vilnius 2011). She also co-edited (with Steve Wilmer) Interrogating Antigone in Postmodern Philosophy and Criticism (Oxford University Press, 2010) and Deleuze and Beckett (Palgrave Macmillan, 2015). audronezukauskaite@takas.lt 


\section{Nomadic Performativity and the Immanent Ethics of Life}

\section{AUDRONĖ ŽUKAUSKAITÉ}

\section{INTRODUCTION}

In their works, Gilles Deleuze and Félix Guattari discern two fundamental principles, which constantly oppose each other: these are the nomadic versus the sedentary distribution of space, the smooth versus the striated, the organism versus the body without organs, and the plane of organization versus the plane of consistency. If classical thought is based on the model of representation, which asserts a certain identity between the world and our thoughts and imagination, by contrast nomadic thought relies on differences and disparities, which are seen as an active medium for the creation and invention of new art forms. Nomadic thought refers not to identities but to multiplicities, not to "organic representation" of what already is but to what is still in the process of creation. The essay will make an indirect comparison between this shift from classical thought to nomadic thought, from representation as identity to creation as differentiation, and the shift from the theatre of representation to the process of performativity. Although Western theatre has its own history and patterns of critique, I will argue that in recent theatrical practices we can discern traces of nomadic performativity, which are very close to Deleuze and Guattari's ideas on nomadology. This essay will discuss Romeo Castellucci's performance series Tragedia Endogonidia as an example of nomadic performativity. Castellucci's performances oppose the principle of organization guiding the theatre of representation and replace it with three strategies: disarticulation of the body, experimentation as the distribution of affects, and desubjectification as nomadism.

\section{WHAT IS NOMADOLOGY?}

The term 'nomadism' became almost a keyword in contemporary theory, mostly because of Rosi Braidotti's use of the term. In her books from Nomadic Subjects (1994) to Nomadic Theory (2011), Braidotti uses the term 'nomadism' to refer to fluid and metamorphic subjectivity as opposed to the clearly defined metaphysical notion of subjectivity. ${ }^{1}$ Gilles Deleuze first used the concept of nomadism in Difference and Repetition and it is elaborated in $A$ Thousand Plateaus, co-written with Félix Guattari. For Deleuze, nomadism means a unique relationship with space and a special distribution of being, which creates a new type of ontology. This new type of ontology not only reshapes our understanding of what is philosophy but also has important implications for science and art, and, as I will argue later, creates the conditions for nomadic performativity.

In Difference and Repetition, Deleuze introduces the term 'nomadism' in his discussion of two different ways of distribution of being: the first one is called sedentary and implies a dividing up of that which is distributed, whereas the second one is called nomadic and is "without property, enclosure or measure". It implies, "no longer a division of that which is distributed but rather a division among those who distribute themselves in an open space - a space which is unlimited, or at least without precise limits". ${ }^{2}$ Sedentary distribution of being implies measurement, division and calculation, whereas nomadic distribution implies an intensive relationship with what is distributed. These two examples - of sedentary and nomadic distribution - refer to two different ontologies. In classical thought, 
ontology is understood in terms of representation with its four characters or modes: identity, analogy, opposition and resemblance. Daniel W. Smith names this type of ontology analogical and argues that "[e]very philosophy of the categories, from Aristotle through Kant and Hegel, implies an analogical ontology". ${ }^{3}$ By contrast to analogical ontology, based on a certain type of identity, Deleuze suggests differential ontology, based not on identity but on differences. Differential ontology implies "an errant and even 'delirious' distribution, in which things are deployed across the entire extensity of a univocal and undistributed Being. It is not a matter of being which is distributed according to the requirements of representation, but of all things being divided up within being in the univocity of simple presence (the One-All)." In this sense Being includes and embraces all individuating differences without reducing them to identity or submitting to a certain hierarchy. By contrast to analogical ontology, based on patterns of representation (analogy, identity, opposition, resemblance), differential ontology encompasses all individuating differences in a univocal chorus. "Univocal being is at one and the same time nomadic distribution and crowned anarchy." 5

In $A$ Thousand Plateaus Deleuze and Guattari give a slightly different definition of sedentary and nomadic distribution relating them to striated and smooth space. Here, nomadic nomos refers to a specific kind of distribution, which means law without law, or law that does not rely upon any organizational principle. Nomadic nomos is opposed to the sedentary type of distribution, or logos, which also means law but it is law which structures and organizes. Logos operates within the walls of the polis, which means organized and structured political life, whereas nomos means anarchic and chaotic distribution as a way in which a nomad inhabits a steppe or a desert. The organized and structured relation to space is called striated, whereas the nomadic relation to space is called smooth: "sedentary space is striated, by walls, enclosures, and roads between enclosures, while nomad space is smooth, marked only by 'traits' that are effaced and displaced with the trajectory". ${ }^{6}$ If striated space is the result of measurement and counting, smooth space is occupied without counting, ${ }^{7}$ in other words, it means not an extensive but an intensive relationship to space. "That is why smooth space is occupied by intensities, wind and noise, forces, and sonorous and tactile qualities, as in the desert, steppe, or ice. [...] Striated space, on the contrary, is canopied by the sky as measure and by the measurable visual qualities deriving from it". 8

Although the smooth and the striated are discussed as two opposing spaces, Deleuze and Guattari maintain that these two spaces exist only in mixture: "smooth space is constantly being translated, transversed into a striated space; striated space is constantly being reversed, returned to a smooth space". Even if in fact these two spaces exist in mixture, this does not preclude a de jure or abstract distinction between them. Deleuze and Guattari argue that the smooth and the striated can be considered as two fundamental principles defining not only mathematical, technological, physical models, but also art. But before discussing the example of art, which is more relevant to our topic, let's take a mathematical example: Deleuze and Guattari oppose Euclidean space and Riemannian space as examples of the striated and the smooth. In the Euclidean space we encounter metric and extensive multiplicities: for example, the magnitude of a vertical line between two points can be compared to the magnitude of a horizontal line between two other points. This comparison is impossible in Riemannian space, where the linkage between two points (or two vicinities) can be effected in an infinite number of ways. "Riemann space at its most general thus presents itself as an amorphous collection of pieces that are juxtaposed but not attached to each other." 10 In other words, what we encounter here is not metric and extensive but non-metric and intensive multiplicities. The latter can also be called nomadic multiplicities, which populate not only Riemannian space but also modern art.

Another example of the smooth and the striated is related to art. Deleuze and Guattari make a distinction between the figurative and the abstract line: the figurative line is characteristic of art based on imitation and representation, whereas the abstract line is detached from the model of representation. Following Wilhelm Worringer, a German art historian, Deleuze and Guattari consider the abstract 
line as something which expresses "will to art". This is the line of variation, "streaming, spiraling, zigzagging, snaking", which liberates the power of life, usually confined in the forms of organization and organism. ${ }^{11}$ At the same time we can observe that the abstract line is described in a way which is very close to the Riemannian space: "a line that delimits nothing, that describes no contour, that no longer goes from one point to another but instead passes between points, that is always declining from the horizontal and the vertical and deviating from the diagonal, that is constantly changing direction [...] - such a line is truly an abstract line, and describes a smooth space" ${ }^{12}$ In this sense the abstract line expresses the smooth space of art and the figurative line refers to the striated space of art. Deleuze, following Worringer, exemplifies such an abstract line in Gothic art, which refers to the power of expression in general. By contrast, the figurative line and the striated forms of art are referred to as organic, which is understood not as something represented but above all as a form of representation. The organic and the organism exist in conformity with metric and striated space. The organism itself is the rectification and striation of life. However, as Deleuze and Guattari explain, "[i]f everything is alive, it is not because everything is organic and organized but, on the contrary, because the organism is a diversion of a life". ${ }^{13}$ This is why to the striated forms of life, which underlie the model of representation, Deleuze and Guattari oppose the smooth space and the abstract line, which express the power of nomadic art.

To explain the notion of nomadic art we have to evoke another concept - that of the body without organs, which Deleuze and Guattari take from Antonin Artaud. If representation is always "organic" and organizing, then what comes to replace it is the body without organs. As Deleuze explains in Francis Bacon, "[t]he body without organs is opposed less to organs than to that organization of organs we call an organism" ${ }^{14}$ It is an intensive body, defined not by forms of representation but by affective variations. This is the body of Francis Bacon's paintings: naked flesh and affection, waves of sensation, forces acting on the body. As Deleuze points out, "[w]hen sensation is linked to the body in this way, it ceases to be representative and becomes real...". ${ }^{15}$ In other words, organic representation of the body is replaced with the body without organs as an indeterminate body or the body whose organs are temporary and transitory. The inspiration for this indeterminate body is, of course, Artaud and his war against organs: "No mouth. No tongue. No teeth. No larynx. No esophagus. No belly. No anus." ${ }^{16}$ Artaud fights not only against an organism but against all forms of organization, including authorship, theatre and representation. In this sense nomadic art expresses art purged from conventional forms of subjectivity and from its representations.

The notion of the body without organs is a central term in $A$ Thousand Plateaus, where it refers to the experimental practices of the hypochondriac, paranoid, schizoid, drugged, or masochist body. It is a body which, following Artaud, wages a struggle against the organs and the organism, against the system of organization. Contrary to the organized and stratified body, the body without organs creates intensities. The organs are not subjected to organism but distribute themselves anarchically on the body without organs or the plane of consistency: "forms become contingent, organs are no longer anything more than intensities that are produced, flows, thresholds, and gradients. 'A' stomach, 'an' eye, 'a' mouth: the indefinite article does not lack anything; it is not indeterminate or undifferentiated, but expresses the pure determination of intensity, intensive difference." ${ }^{17}$ In other words, this is a nomadic distribution of intensities, which destroys the stratified forms of organization and invents new forms of sensation and subjectivity. Deleuze and Guattari interpret Artaud's Héliogabale and Les Tarahumaras as producing the continuum of such intensities: "These two books by Artaud express the multiplicity of fusion, fusionability as infinite zero, the plane of consistency." 18 This nomadic distribution of intensities is the crowned anarchy to be reached to evade the organism, organization and stratification.

It seems that Artaud's experimental practices are crucial for Deleuze and Guattari to formulate their notion of the body without organs. However, it is not a coincidence that the notion of the body without organs is used to analyze Artaud's notion of theatre and to define nomadic performativity. Similarly, as the body without organs denies any forms 
of organization, Artaud's theatre denies all forms of representation, such as authorship, role, text, genre or recording. As Edward Scheer points out, Artaud's work is directed against the representational theatre and its stratified forms: "So the body without organs defies not only particular instances of the body, but the entire matrix of representations within which bodies, forms and roles are circulated and define each other." 19 The body is the medium for affection and sensation, a zone where intensities circulate and pass. As such, Artaud's theatre transgresses not only the boundaries of the body but also the boundaries of theatre as an art form. As Scheer points out, Artaud's theatre "has to begin making the body without organs, freeing life of its inauthentic attachments to representation and reconnecting it to the forces that underlie all forms. The theatre of cruelty is not therefore a theatre as such, but an entity defined by a fundamental conflict with theatre, a critique of all the institutional practices (the organs) of the theatre in the name of a principle of vitality that dissolves 'notre petite individualité humaine' (our trivial human individuality)." ${ }^{20}$ We can claim that theatre becomes nomadic not only in the sense that all its conventional forms start shifting and trembling but in the sense that it becomes a non-representable life flow, which is asignifying, asubjective and inorganic.

Deleuze expresses very similar ideas in "One Less Manifesto", his only text directly dedicated to theatre and to Carmelo Bene's productions. Commenting on the structural deformations of Bene's work, Deleuze argues that these deformations create the instance of non-representational theatre and in this way continue the experiments practiced by Artaud, Grotowski, and the Living Theater. ${ }^{21}$ In referring to Artaud's theatre Deleuze (and Guattari) describe it in terms of the body without organs and crowned anarchy, whereas discussing Bene's theatre in "One Less Manifesto" Deleuze defines it in terms of continuous variation. Using some specific procedures - such as amputation and subtraction Bene destroys all elements of theatre that constitute power or identity - an author, an actor, a director, a text, a character. He destroys any identity and the possibility to replicate this identity by representing it. As Deleuze points out, "you begin by subtract- ing, deducting everything that would constitute an element of power, in language and in gestures, in the representation and in the represented. You cannot even say that it is a negative operation because it already enlists and releases positive processes." ${ }^{22}$ These positive processes inaugurate a new kind of theatre, based not on representation and identity but on continuous variation and differentiation. In other words, if theatre as a form of representation creates a striated and hierarchized space which embodies and increases power, the non-representational theatre creates a nomadic smooth space of continuous variation, which transposes everything into a constant becoming.

As I argued elsewhere ${ }^{23}$, Deleuze interprets this shift towards non-representational theatre as a political move, which destroys representation as an instrument of power and allows for so-called minority consciousness. As Deleuze suggests, minor theatre has "to transmit everything through continuous variation as on a creative vanishing line that constitutes a minor tongue in language, a minor character on the stage, a set of minor transformation in relation to dominant forms and subjects". ${ }^{24}$ Deleuze argues that minor theatre has to replace the majority rule of Nobody with the minority becoming of everything. In this sense an "antirepresentational function would be to trace, to construct in some way, a figure of the minority consciousness as each one's potential. To render a potentiality present and actual is a completely different matter from representing a conflict." ${ }^{25}$ Thus, Deleuze sees minor theatre as a medium to create a nomadic subjectivity capable of becoming and undergoing a creative change. "Theater will surge forward as something representing nothing but what presents and creates a minority consciousness as a universal-becoming. It forges alliances here and there according to the circumstances, following the lines of transformation that exceed theater and take on another form..."26 Thus, minor theatre creates minority consciousness, not in the sense that it includes minorities (although it fulfills this mission as well), but by opening the potential for universal becoming which means "becoming-other". In this respect, minor theatre recuperates all meanings of nomadic performativity, discussed above: first, it is a distribution 
of intensities, which come to replace forms, bonds, organized hierarchies; second, it refers to fusional multiplicities rather than self-identical subjects; and third, it opens the potential for change and becoming-minor instead of representing major figures of power.

\section{NOMADIC PERFORMATIVITY: ROMEO CASTELLUCCI'S TRAGEDIA ENDOGONIDIA}

The notion of nomadic performativity can be elaborated discussing Romeo Castellucci's performance series Tragedia Endogonidia, which consists of eleven episodes, performed in ten European cities in 20022004. Castellucci is not a random example here, not only because he, as a teenager, saw a performance by Bene and apparently was influenced by this event to make theatre himself, ${ }^{27}$ but also because his performance philosophy is very much indebted to Deleuze and Guattari. Like Deleuze, Castellucci makes a sharp distinction between conventional forms of theatre, such as Attic tragedy, and his own invention of performance as a self-generating organism. Along the same lines, he distinguishes between theatre as a representation of power and performance as a medium for minority consciousness and the "people to come". Castellucci refers to the ambivalent role of the theme of tragedy in our society: on the one hand, tragedy is considered to be the fundamental mode of human expression; on the other hand, in the society of the spectacle, our lives are completely detached from any concept of the tragic. As Castellucci points out, "[d]isasters and the slaughters of innocents are everywhere referred to as 'tragedies', but this is an idea of tragedy that does not know how to distinguish these things from spectacle; nor how to think of them in terms of political crisis; nor how to gather them up on behalf of a metropolitan community, amongst people who are at the same time amassed and dispersed, who lack any common ground or mother language, who lack even 'a people': who lack those foundations that are the basis for the invention of tragedy". ${ }^{28}$ To invent and visualize these "people to come", contemporary theatre has to question the conventional forms of Attic tragedy and introduce a new model of nomadic performativity.
In this context we can argue that Castellucci's performance series Tragedia Endogonidia questions the very idea of theatre as representation. As the title implies, the tragedy here is confronted with the power of life and its capacity for self-generation. The word 'endogonidia', adapted from the vocabulary of microbiology, "refers to those simple living beings with two sets of sexual organs inside themselves that are able to reproduce continually, without need of another, according to what amounts, effectively, to a system of immortality". ${ }^{29}$ Similarly, the performance series, consisting of eleven episodes, is understood as a process of evolution and progressive differentiation, where every episode is generated and governed by its own logic. In this sense the concepts of "tragedy" and "endogonidia" are antithetical even if both of them refer to immortality: tragedy refers to immortality as transcendence, whereas "endogonidia" refers to immortality as a continuous process of self-generation and progressive differentiation. According to Claudia Castellucci, "[t]ragedy fixes death. 'Endogonidia', on the other hand, designates the perennial life of an individual that, splitting itself, continually self-generates. And so Tragedia Endogonidia produces the continuous fixing of those deaths that succeed each other ceaselessly. Anonymity, nocturnal darkness, the privation of words, alphabetic and microbial invasion in league with the law, these are the initial conditions of our tragedy." 30

Defined in this way, Tragedia Endogonidia proceeds like an organism on the run, making connections and disjunctions with the environment encountered in every city where it takes place. Without a predetermined script or narrative, these performances present a series of transformations, which interconnect actors, machines, animals, and visual-acoustic sensations into a univocal multiplicity. The figures on the stage undergo different kinds of becoming, changing genders (becoming-woman), species (becoming-animal), and even disappearing (becoming-imperceptible). In other words, Tragedia Endogonidia, understood as a process of transformation and progressive differentiation, runs counter to the Aristotelian notion of tragedy as a "whole" or an organism, with a beginning, middle and end. Instead it creates the body without organs, which expresses the evolutionary and partial nature 
of life processes and the affective and sensational nature of artwork.

Following this we can formulate an opposition between tragedy as a closed system of representation (a whole or an organism) and "endogonidia" as a process of self-generation (the body without organs). Similarly, Deleuze and Guattari in A Thousand Plateaus define two competing principles or "planes": the plane of organization and the plane of consistency or immanence. The plane of organization (or plane of transcendence) "organizes and develops forms (genres, themes, motifs) and assigns and develops subjects (personages, characters, feelings)", and in this sense can be seen as a system of both representation and subjectification. And there is another plane, where there "are only speeds and slownesses between unformed elements, and affects between nonsubjectified powers". ${ }^{31}$ This is the plane of immanence or the body without organs. Therefore we can argue that Tragedia Endogonidia with its processes of self-generation can be placed on the plane of immanence, where it reproduces itself, divides, multiplies, and follows its "lines of flight". What is important to stress here is that the plane of organization (or transcendence) always works on the side of power, whereas the plane of consistency or the body without organs opens space for connections, conjunctions and distributions of intensity.

Referring to Artaud's radio work To Have Done With the Judgment of God, Deleuze and Guattari argue that the judgment of God is the operation of power, which imposes on us "forms, functions, bonds, dominant and hierarchized organizations, organized transcendences". ${ }^{32}$ The judgment of God uproots the body from its immanence and makes it an organism, a signification, a subject. To oppose the judgment of God Artaud invents the body without organs, which is an "affective, intensive, anarchist body that consists solely of poles, zones, thresholds, and gradients. It is traversed by a powerful, nonorganic vitality." ${ }^{33}$ In other words, the judgment of God presupposes the three great strata that most directly bind us to the structures of power the organism, signification, and subjectification. To these three strata, the body without organs opposes the disarticulation of the body, experimentation as the distribution of affectivity, and desubjectification as nomadism. In this context, nomadism acquires a slightly different meaning: it refers not only to becoming-everything but also to desubjectification as the total erasure of conventional forms of subjectivity.

Thus, the first strategy to oppose the judgment of God is the disarticulation of the body. Castellucci, like Artaud and Bene, disrupts the organic unity of the body and rearranges it as an assemblage collected from different surfaces, prosthetic devices, machines and mechanisms. In this sense, we can say that Castellucci invents the body without organs $-\mathrm{a}$ body which is not organized into a coherent identity or unity but which functions as a platform for producing different connections and distributing variable intensities. As Claudia Castellucci points out, "[i]n Tragedia Endogonidia, there is always something that can be turned inside out, or turned into its own negative. Skins, hoods, sacks, sheaths, gloves, placentas and ski-masks extend the body into an ulterior dimension, through a change of form or sex, or through lines of flight that also function through disguises and masks and that slip through our attempts to intercept them, so that it is impossible to recognize the object anymore, due to this intervention of general communication." ${ }^{34}$ In the Cesena episode, there are two scenes in which the reversal of the skin is shown. The first scene is that of the Anonymous Mother: here, the male actor appears 'wearing' the skin of a woman, which he takes off at the end thus revealing his male nudity.

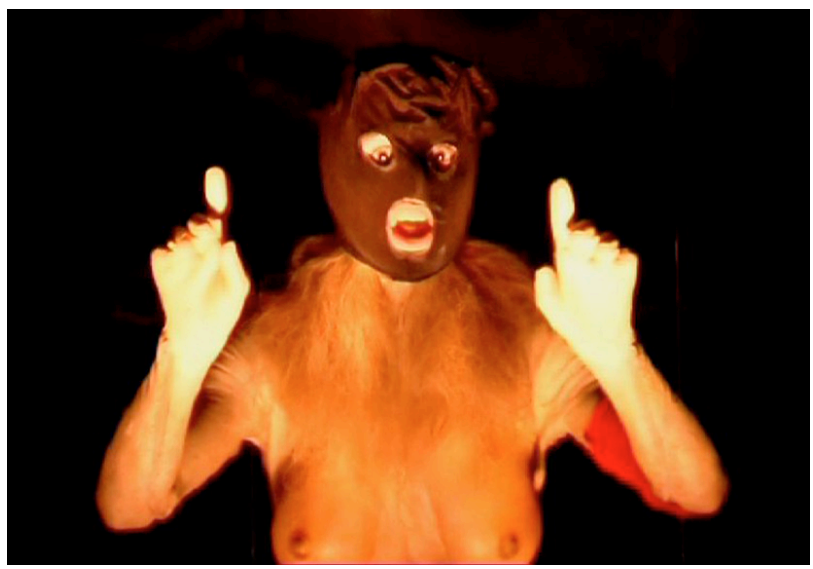

Fig. 1. Video still from Tragedia Endogonidia (2002-2004), Cesena, directed by Romeo Castellucci, video memory by Cristiano Carloni, Stefano Franceschetti, 2002-2004. 
In the second scene, "a pair of childlike legs descends from above showing female genitalia. At a certain point, these legs are turned inside out like a glove, dispersing a great quantity of blood, which pours down upon the stage. They are identical to how they first appeared, except with male genitalia instead of female." 35 Thus, the character suffers not

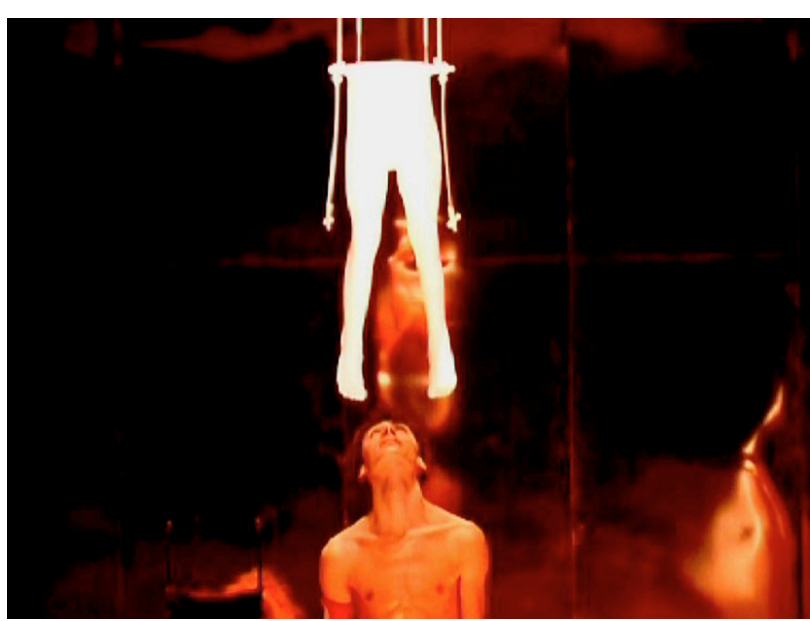

Fig. 2. Video still from Tragedia Endogonidia, Cesena.

only the transformations of gender but also his status as a subject. Claudia Castellucci compares this scene with Maurice Merleau-Ponty's phrase about "the two leaves of the body": the interior and the exterior sides of the skin are articulated one upon the other. "[I]n the reversibility of the skins, Claudia Castellucci comments, the Self becomes an object of contact, of the world and taken from the world." ${ }^{36}$ Castellucci not only transforms the body but also relates it to different mechanisms, or to an-

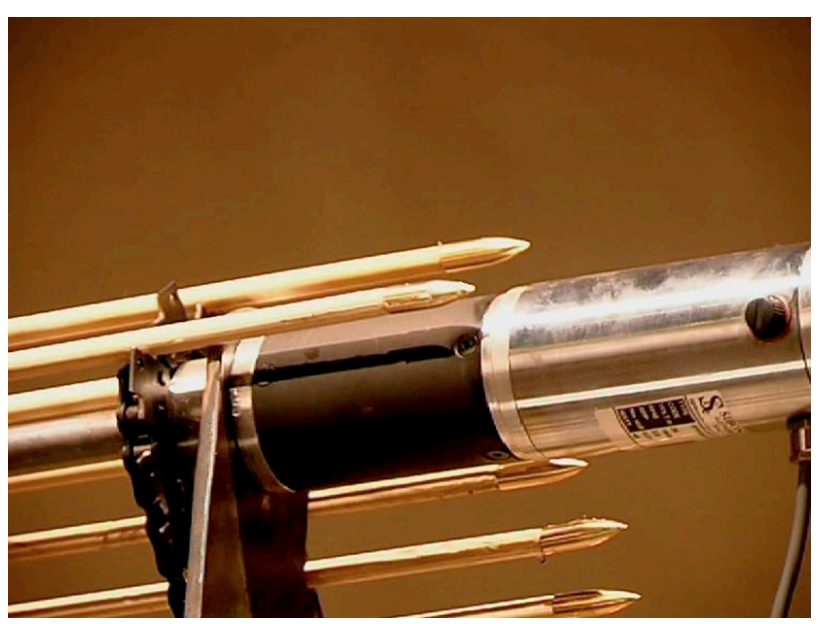

Fig. 3. Video still from Tragedia Endogonidia, Cesena. imals, or to mediated reality. For example, in the Cesena episode, mentioned earlier, the scene where the male actor is 'wearing' a woman's body is interrupted by another performance enacted by a mechanical bow. This mechanical actor not only embodies Deleuze and Guattari's notion of a machine of desire but also implies that all bodies - biological or mechanical - operate on the same plane of the body without organs.

Another strategy to oppose the judgment of God is the replacement of the system of signification with experimentation and affectivity. For Deleuze and Guattari, the body without organs is a platform of experimentation where different intensities circulate and pass. Thus, instead of interpreting the body in terms of signification (and asking, "What does it mean?"), they suggest that we should examine it in terms of affect ("How does it work? What affects can it produce?"). Similarly, Castellucci replaces the communicative and cognitive function of language with the power of affects, which directly affect the audience. As Castellucci argues, "[o]ne of the political tasks of the theatre [...] is to get right to the bottom of its own specific language. Without fear either of incomprehension or the impossibility of communication; without translation or commentary or explanation; [...] with a strategy for words and a strategy for images that is capable of organising a new reality. This, in short, is what the movement of Tragedia Endogonidia is all about..." 37 Thus Castellucci's performances are full of signs which have irretrievably lost their signification. This strategy is close to that of Artaud who thought that language is a means of repression and therefore invented a new language glossolalia, which produces not meaningful statements but immediate affects on the body. As Claudia Castellucci indicates, the system of signification conveys no meaning and creates no communication: "there is a strong analogy between money and the alphabet: the impersonal character of mediation is present in both. They don't look anyone in the face, so to speak. They are amoral and apolitical. As casual as you like, they pass from one regime to another, without disintegrating or changing their function." ${ }^{38}$ The disintegration of the communicative and cognitive function of language is obvious in the Avignon episode, which ends with 


\section{$M$}
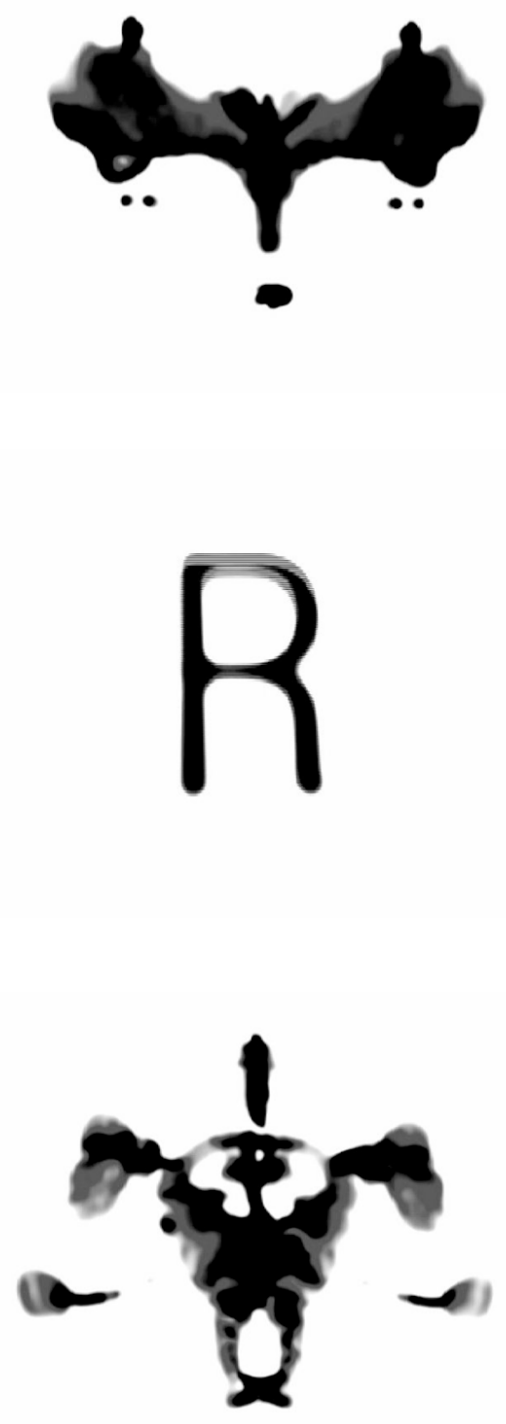

Fig. 4-7. Video still from Tragedia Endogonidia, Avignon. a sequence of letters that are randomly replaced by Rorschach blots.

This sequence does not convey any meaning but functions as an intense attack of affects, provoking our senses. As Claudia Castellucci points out, "through the projection of the final video, which shows a percussive sequence of letters of the alphabet, there is a demonstration of power, which is even more violent when the frequency of the switches between black letters and white background is increased. [...] The speed of this alternation of signs upon an empty surface overwhelms our 'capacity', because everything becomes sign, even the white around the black letters, even the black Rorschach blots, which, in the end, alternate with the letters." ${ }^{39}$

The third strategy to oppose the judgment of God is desubjectification as constant becoming. By desubjectification Deleuze and Guattari mean the quest for the impersonal and even the non-human. Besides this, desubjectification also refers to the deconstruction of the majoritarian subject in order to make visible those subjectivities, which are invisible on the political scale. Claudia Castellucci proposes that the real protagonist of their performances is anonymity itself: the anonymous figure "recalls 'no one', an indistinct member of the crowd... This is not a hero: it is a whoever person." ${ }^{40}$ This renunciation of one's own identity echoes Deleuze and Guattari's notion of becoming-minoritarian, becoming-everything (devenir tout le monde): the task of minor politics (and minor theatre) is not to establish a new political identity but to liberate the process of becoming-minoritarian. "In erecting the figure of a universal minoritarian consciousness, one addresses powers (puissances) of becoming that belong to a different realm from that of Power (Pouvoir) and Domination. [...] Becoming-minoritarian as the universal figure of consciousness is called autonomy. It is certainly not by using a minor language as a dialect, by regionalizing or ghettoizing, that one becomes revolutionary; rather, by using a number of minority elements, by connecting, conjugating them, one invents a specific, unforeseen, autonomous becoming." ${ }^{41}$ Thus, the concept of becoming-minoritarian could help to explain the meaning of the figure with a covered face, which often appears in Castellucci's performances: to cover 
one's face means to take the position of a minority or to make its absence visible: "To cover the face is a new act of appearing, of making present. [...] These days, theatre doesn't look towards the ancient masks, nor to the veristic faces of realism, but rather to the ski-mask." 42

The ski-mask refers to Carlo Giuliani, the young demonstrator killed by Italian police during the protests at the G8 Summit in the summer of 2001. The media dispersed the images of his anonymous body with his face covered by a ski-mask. Covering a face with a ski-mask on the stage means something opposite: to disclose the structures of power and make violence visible. The task of political theatre in this sense is to stage the events which officially "did not happen" because they have no place in the public space. This is the way we can interpret the scenes of violence in Castellucci's performances. For example, in the Brussel episode an actor in a police uniform enters the stage. He pours artificial blood and marks
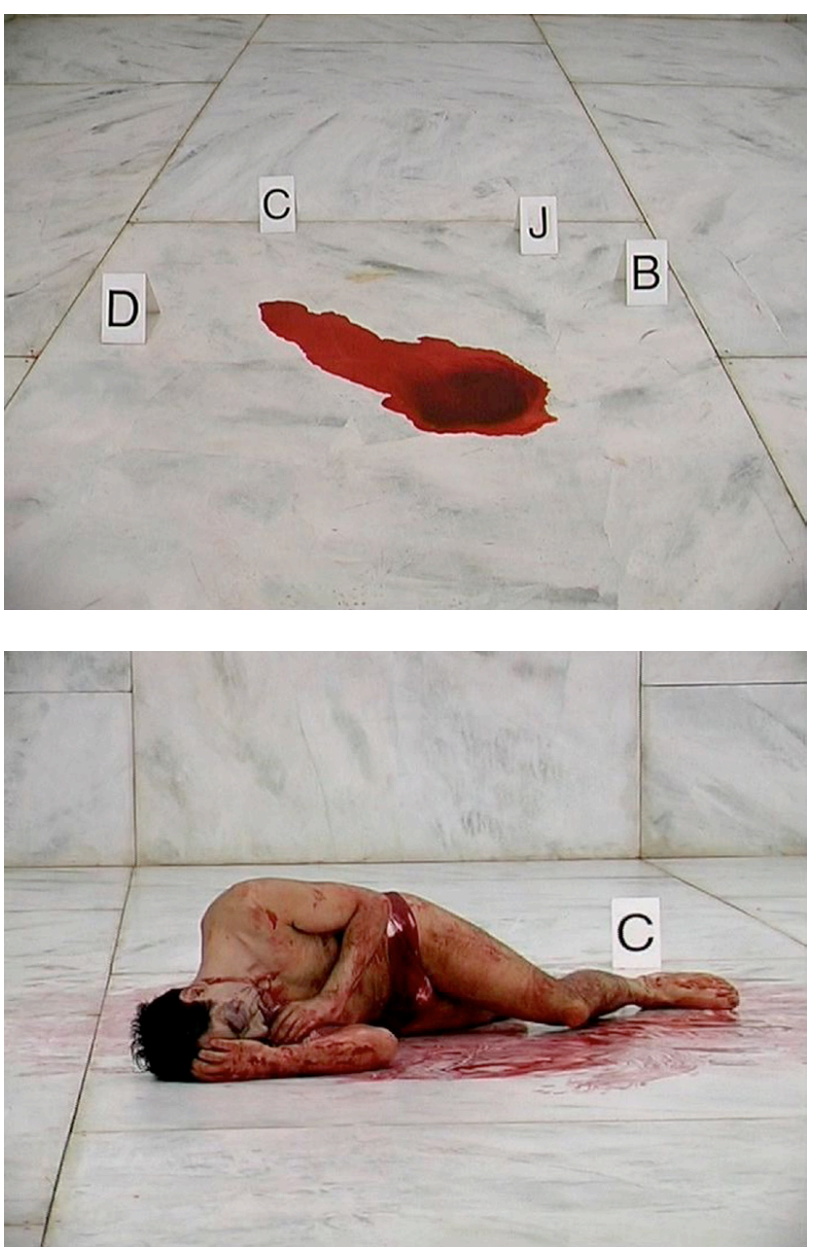

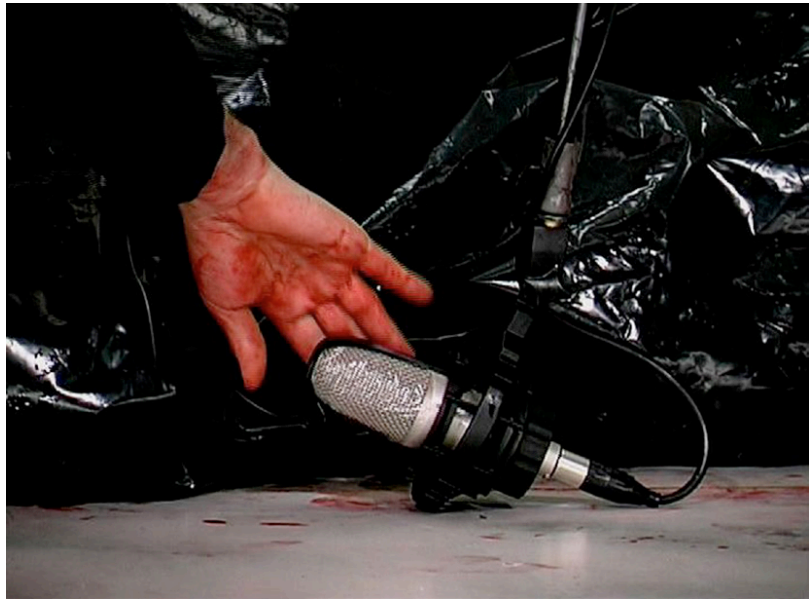

Fig. 8-10. Video still from Tragedia Endogonidia, Brussel.

the stain with lettered cards. Two other policemen enter and one of them undresses and lies down on the blood. His colleagues start beating him.

Even if we know that the violence on the stage is not real - the blood is artificial, the blows do not actually hurt - the suffering it produces is more than real. Even though in police reports this event "did not happen", the privilege of the theatre is to let these events be shown and, we should say, "shown twice over". ${ }^{43}$ In this respect, Castellucci's performances are very close to Artaud's theatre of cruelty: as Artaud explains, we need to invent the system of cruelty in order to oppose the system of judgment. The system of cruelty creates a body without organs - an asubjective, disorganized body, - which evades the system of judgment (the system of power) by creating a platform for continuous variation and becoming. Similarly, Castellucci's performances deconstruct the majoritarian model of subjectivity and replace it with a universal becoming-minoritarian. Tragedia Endogonidia replaces the system of power and subjection with the system of cruelty, the "universals of language" - with affectivity and experimentation, the representation of identity - with anonymity and minority consciousness.

In this sense Tragedia Endogonidia follows the principle of life, which functions as the ethical principle of Deleuze's philosophy. The vitalist energy of life creates an immanent ethics, which can be traced to Deleuze's Spinoza: Practical Philosophy. Here he defines the difference between the trans- 
cendent field of morality and the immanent field of ethics. Deleuze asserts that Spinozian ethics comes to replace morality, just as the qualitatively different modes of existence come to replace the transcendent values or the judgement of God: "Morality is the judgment of God, the system of Judgment. But Ethics overthrows the system of judgment. The opposition of values (Good-Evil) is supplanted by the qualitative difference of modes of existence (good-bad)." ${ }^{44}$ Following Spinoza and Nietzsche, Deleuze argues that "good" are those modes of existence which increase our powers of acting, and "bad" are those which keep us in a state of passive slavery. Thus the ethical principle of life defines not only human or non-human subjectivity but is also the principle of creation and art. As Daniel W. Smith argues, art has no other object than life, and "that a 'passage of Life' can only be seen or felt in a process of creation, which gives the non-organic and impersonal power of Life a consistency and autonomy of its own, and draws us into its own becoming". ${ }^{45}$ In this sense, nomadic performativity can be seen not as becoming-everything but more as an ethical principle of vitality and life. 


\section{NOTES AND REFERENCES}

1 See Rosi Braidotti, Nomadic Subjects: Embodiment and Sexual Difference in Contemporary Feminist Theory, Columbia University Press, New York 1994; Rosi Braidotti, Metamorphoses: Towards a Materialist Theory of Becoming, Polity Press, Cambridge 2002; Rosi Braidotti, Transpositions: On Nomadic Ethics, Polity Press, Cambridge 2006; Rosi Braidotti, Nomadic Theory: The Portable of Rosi Braidotti, Columbia University Press, New York 2011.

2 Gilles Deleuze, Difference and Repetition, trans. by Paul Patton, Continuum, London, New York 2004, p. 46.

3 Daniel W. Smith, Essays on Deleuze, Edinburgh University Press, Edinburgh 2012, p. 39.

4 Deleuze, op. cit., p. 46.

5 Ibid., p. 47.

6 Gilles Deleuze, Félix Guattari, A Thousand Plateaus: Capitalism and Schizophrenia, trans. by Brian Massumi, Continuum, London 2004, p. 420.

7 Ibid., pp. 430, 527.

8 Ibid., pp. 528-29.

9 Ibid., p. 524.

10 Ibid., p. 535.

11 Ibid., p. 550.

12 Ibid., p. 549.

13 Ibid., p. 550.

14 Gilles Deleuze, Francis Bacon, trans. by Daniel W. Smith, Continuum, New York, London 2005, p. 32.

15 Deleuze, op. cit., p. 33.

16 Cited from ibid.

17 Deleuze, Guattari, op. cit., p. 182.

18 Ibid., p. 175.

19 Edward Scheer, "I Artaud BwO: The Uses of Artaud's To have done with the judgement of god" in Deleuze and Performance, Laura Cull, ed., Edinburgh University Press, Edinburgh 2009, p. 43.

20 Ibid., p. 45.

21 Gilles Deleuze, "One Less Manifesto" in Mimesis, Masochism, and Mime: The Politics of Theatricality in Contemporary French Thought, Timothy Murray, ed., University of Michigan Press, Ann Arbor 1997, p. 241.

22 Deleuze, “One Less Manifesto”, op. cit., p. 245.

23 Audronė Žukauskaitė, "The Post-subjective Body, Or Deleuze and Guattari Meet Romeo Castellucci” in Performance, Identity, and the Neo-Political Subject, Matthew Causey, Fintan Walsh, eds., Routledge, London, New York 2013, p. 107.

24 Deleuze, “One Less Manifesto”, op. cit., pp. 251-2.
25 Ibid., pp. 253-4.

26 Ibid., p. 256.

27 Claudia Castellucci, Romeo Castellucci, Chiara Guidi, Joe Kelleher, Nicholas Ridout, The Theatre of Societas Raffaello Sanzio, Routledge, London, New York 2007, p. 19.

28 Ibid., p. 30.

29 Ibid., p. 31.

30 Ibid., p. 29.

31 Deleuze, Guattari, op. cit., p. 295.

32 Ibid., p. 176.

33 Gilles Deleuze, “To Have Done With Judgment” in Essays Critical and Clinical, trans. by Daniel W. Smith and Michael A. Greco, University of Minnesota Press, Minneapolis 1997, p. 131.

34 Castellucci et al., op. cit., pp. 66-7.

35 Ibid., p. 67.

36 Ibid.

37 Ibid., p. 29.

38 Ibid., p. 69.

39 Ibid., pp. 69-70.

40 Ibid., p. 68.

41 Deleuze, Guattari, op. cit., p. 118.

42 Castellucci et al., op. cit., p. 69.

43 Ibid., pp. 100-1.

44 Gilles Deleuze, Spinoza: Practical Philosophy, trans. by Robert Hurley, City Lights Books, San Francisco 1988, p. 23.

45 Smith, op. cit., p. 221. 